\title{
Utilization and Management of Eucheuma cottonii Seaweed and Cassava
}

\author{
Makosembu Walaluya ${ }^{1}$, Vyneyia Lilabite ${ }^{2}$
}

\author{
'Zanzibar University, Tanzania
}

\section{${ }^{2}$ University of Khartoum Institute of Environmental Studies, Sudan}

\begin{abstract}
This paper discussed all about seaweed utilization and management. The method that used in the form of experiments conducted by making various kinds of seaweed formulas, casava flour with a mixture of wheat flour. After that, an examination was carried out to determine the durability of the seaweed noodles by comparing the seaweed noodles placed in the refrigerator and in an open room. Seaweed (Eucheuma cottonii) and cassava flour have a lot of protein content so that they can be made into something of high value, namely seaweed noodles, because the ingredients are easy to obtain and good for consumption by the body's growth. Apart from being easy to get, seaweed (Eucheuma cottonii) and cassava are also environmentally friendly because they come from natural ingredients and do not endanger health.
\end{abstract}

Keywords: Seaweed, Cassava, Body's Growth

\section{Introduction}

A country that is rich in agricultural products. Both from the land and sea products (Dhargalkar \& Pereira 2005). Seaweed, maybe that name is familiar to our ears, especially for coastal communities. However, not many people know the benefits of seaweed. There are many benefits that we can get by consuming seaweed. For some people Seaweed is only commonly used as a staple ingredient for making gelatin and as a complement to fruit ice, but Seaweed can also be used as a new discovery that is more unique and of high value. For example, it can be made into noodles. Currently, many people consume noodles as a food supplement. While the basic ingredients in making noodles are very expensive and also use harmful ingredients such as the use of borax for thickening, which is very dangerous for health. Therefore, researchers must look for alternatives to the basic ingredients of noodles, namely seaweed. The chewy nature of seaweed can be used as a staple for making noodles and as a substitute for borax, so seaweed noodles are safer and healthier because they are made from natural ingredients. This idea was obtained after knowing that some people in coastal consume instant noodles and meatballs almost every day. Even though this food is very dangerous to health. By processing marine resources it becomes more useful and can help ordinary people to make their own noodles without having to use expensive materials and materials that endanger human lives because they contain many chemicals, and can increase the income of the people.

\section{Morphology of Seaweed (Eucheuma cottonii)}

In terms of morphology, seaweed does not show any differences between roots, stems and leaves. Seaweed thalus has various forms, including round, flat, flat and round like pockets, hair and so on (Dawes \& Mathieson 2008). Based on the number of cells that make up these 
algae, some are arranged unicellular (one cell) or multicellular (many cells). In macro algae, the types of branching include pectinate (in line with the main thalus), pinnate (branched in two along the main thalus alternately), ferticilate (branches centered around the main axis or axis) and some are simple, unbranched. The seaweed classification can be seen below:

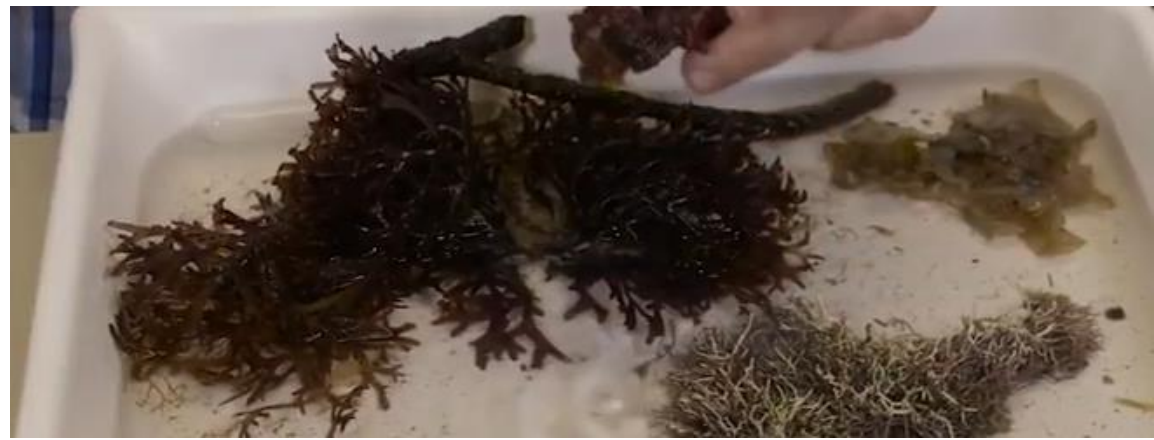

Figure 1. Sapat Seaweed

Table 1. Sapat Seaweed

\begin{tabular}{|l|l|}
\hline Division & Rhodophyta \\
\hline Class & Rhodophyceae \\
\hline Sub class & Florideophycidae \\
\hline Nation & Gigantinales \\
\hline Tribe & Solieraceae \\
\hline Clan & Eucheuma \\
\hline Species & Eucheuma Cottonii \\
\hline
\end{tabular}

Seaweed or algae grows in almost all hydrophic parts to the limit of the depth of sunlight that can still reach it (Deshmukhe et al., 2001). Some types of seaweed live cosmopolitan, worldwide. Seaweed lives as a phytobentho by sticking itself into the substrate of mud, sand and so on. There are basically two kinds of seaweed development, namely in mating (generative) between male gametes and female gametes and non-mating vegetatively, conjugatively and responding (Doty et al., 1987).

Seaweed consists of water (27.8\%), protein (5.4\%), carbohydrates (33.3\%), fat (8.6\%) crude fiber (3\%) and ash (22.25\%). Apart from carbohydrates, protein, fat and fiber, Seaweed also contains enzymes, nucleic acids, amino acids, vitamins ( $A, B, C, D, E$ and $K$ ) and macro minerals such as nitrogen, oxygen, calcium and selenium as well as micro minerals such as iron, magnesium and sodium (Ferdouse et al., 2018; Hwang \& Park 2020). The content of amino acids, vitamins and minerals of seaweed reaches 10 -20 times compared to plant origin, irregularly branched, di or tikotomous (DPK).

\section{Cassava}

Cassava can be found everywhere, especially in tropical areas, cassava tubers are rich in carbohydrates so that they are widely used by everyone (Rebours et al., 2014; Reilly et al., 2008). 
The classification of cassava tubers is as follows:

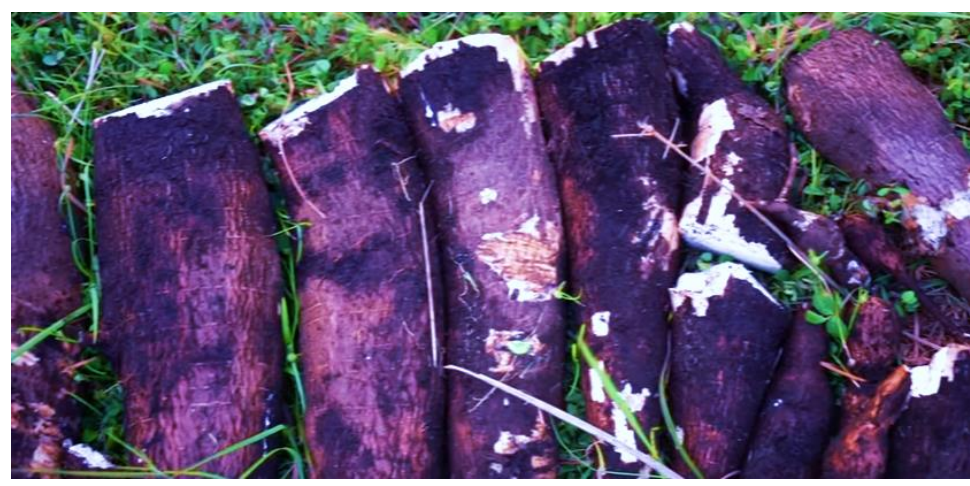

Figure 2. Cassava

Table 2. Cassava

\begin{tabular}{|l|l|}
\hline Kingdom & Plantae \\
\hline Division & Magnoliophyta \\
\hline Class & Magnoliopsida \\
\hline Ordo & Malpighiales \\
\hline Famili & Euphorbiaceae \\
\hline Nation & Manioheteae \\
\hline Genus & Monihot \\
\hline Species & M.esculenta \\
\hline
\end{tabular}

Cassava is a commodity that is easily damaged after being harvested, within 2-3 days if it is not processed or consumed immediately, the tuber will change color to brown, taste bad and even rot. One way to solve this problem is to convert fresh wood into more beneficial flour.

Cassava flour or better known as casava flour can be used to make cakes, noodles or other cake dough. Cassava flour can be used to replace 5-20\% of wheat flour, with this it will save our expenses because of the expensive price of wheat flour, besides that it can help increase farmers' income because cassava is used to make flour. The nutritional content of casava flour is able to provide a high enough amount of energy which is useful for the health of the body. The texture, color and aroma resembles wheat flour.

\section{Making Cassava Flour}

Casava flour or cassava flour is made from cassava flour that is not too old or too young to produce good flour. The processing of cassava flour is to peel the cassava and then wash it thoroughly and grate it. The grated results are squeezed using a cloth and then separate the 
starch from the dregs. The cassava dregs are then dried in the sun to dry, celebrate the dregs until smooth. The starch from the juice can also be mixed with cassava dregs.

\section{Borax}

Borax is a crystalline compound, white in color, odorless and stable at normal pressure temperatures Seghetta et al., 2016; Ugarte et al., 2006). Borax is a dangerous chemical compound for food with the chemical name sodium tetrabonate ( $\mathrm{NaB} 4 \mathrm{O} 7 \mathrm{10H} 2 \mathrm{O})$. Can be found in solid form and if it dissolves in water, it will become sodium hydroxide and boric acid (H3BO3). Borax or boric acid is commonly used as a detergent material, is antiseptic and reduces water hardness. These hazardous materials are haram to use for food. The dangers of borax by inhalation, in contact with skin and if swallowed can cause respiratory tract irritation, skin irritation, eye irritation and kidney damage. If 5-10 grams of borax is ingested by children it can cause shock and death. Acute effects of borax can cause body discomfort, nausea, severe pain in the upper abdomen, bleeding gastro-enteritis accompanied by vomiting of blood, diarrhea, weakness, drowsiness. , fever and headache. Borax abuse for food has been found in noodles, meatballs, crackers and other snacks. To find out foods that contain borox, namely chewy texture, more shiny, not sticky and can not break.

\section{Method}

\section{Types of research}

The type of research used in this paper is a type of qualitative research. Qualitative research is research that explains or reveals the meaning of a concept or experience based on the awareness that occurs in several individuals. This research was conducted in a natural situation, so there are no limitations in interpreting or understanding what is being studied.

\section{Data and Data Sources}

The data obtained in this study are secondary data and obtained through some literature, books and the internet. The data referred to is about the nutritional content in Seaweed and Cassava Flour as well as the dangers of Borax contained in food. The definition of methodology is taken from the book, while the manufacturing process, the quality of the results and the benefits obtained are obtained directly from the notes during the observation.

\section{Data collection technique}

The data collection methods used in this research are experimental methods, documentation, and literature search.

\section{Experiment}

This method is in the form of experiments conducted by making various kinds of seaweed formulas, casava flour with a mixture of wheat flour. After that, an examination was carried out to determine the durability of the seaweed noodles by comparing the seaweed noodles placed in the refrigerator and in an open room.

\section{Documentation}

This method is used to document when the experiment was carried out and the results obtained after the experiment was carried out.

Place and time of research 
Research on the manufacture of seaweed noodles made from seaweed and casava flour with wheat flour was carried out in the Chemical Laboratory of SMAN 1 Gending and in Sebaung Village, Gending District, Probolinggo Regency. Raw materials for grass, casava flour and wheat flour are also obtained from Curahsawo Village, Gending District, Probolinggo Regency. This research was conducted from 22 June - 4 July 2011.

\section{Subject Selection}

The subject studied in this paper is the manufacture of seaweed noodles. Seaweed and cassava flour which are widely available in Probolinggo Regency. The material will be used for manufacturing, capital and profits.

\section{Tools and Materials}

Materials used: (1) seaweed: 341.5 grams; (2) casava flour: 500 grams; (3) wheat flour: 250 grams; (5) water: $300 \mathrm{~mL}$; (6) eggs: 2 eggs. Tools used: (1) blender, (2) plastic basin. (3) knife, (4) baking sheet, (5) pasta machine, (6) electric scale, (7) spoon and solet

Procedure : (1) Seaweed soaked in lime water overnight, (2) The seaweed is washed with clean water then cut the seaweed into small pieces, (3) After cutting the seaweed into small pieces, blend the seaweed with a little water and then filter the fine seaweed and take the water or paste. (4) Prepare the flour and then filter the flour, (5) After finishing filtering, put the flour in a plastic bowl then mix it with the seaweed paste, (6) before the dough is mixed evenly, add the dough with 2 eggs then stir until blended, (7) after the dough is evenly mixed, the dough is catalyzed or mashed by throwing it, (8) after smooth, print adoana on the noodle making machine, (9) After the finished noodles are printed, they are placed on a baking sheet with the remaining flour so that the noodles are not sticky, (10) After all the dough becomes noodles, the noodles are ready to be packaged and cooked

\section{Benefits and Contents contained in Seaweed}

Seaweed (Eucheuma cottonii) has many benefits, one of which is as a dietary food and can cure cancer. The content of seaweed is generally essential minerals (iron, iodine, aluminum, manganese, calcium, soluble nitrogen, phosphorus, sulfur, chlorine, silicon, rubidium, strontium, barium, titanium, cobalt, boron, copper, potassium, and other elements. others), nucleic acids, amino acids, proteins, minerals, trace elements, flour, sugars and vitamins $A, D$, $\mathrm{C}, \mathrm{DE}$, and $\mathrm{K}$. Because of their high nutritional content, they are able to improve the hormonal, lymphatic, and nervous work systems. .

Seaweed also helps treat stomach ulcers, colitis, constipation and other digestive disorders. Therefore we use seaweed as a basic ingredient in making noodles. Due to its high nutritional content, it is able to improve the hormonal, lymphatic and nervous system of work. The chlorophyll content of seaweed is anti-carcinogenic, the high content of fiber, selenium and zinc in seaweed can reduce estrogen. Allegedly, too high estrogen levels can encourage cancer, so consumption of seaweed reduces the risk of cancer and even treats it. Contains ten times higher calcium than milk, so Seaweed is very appropriate. In addition, it is also rich in fiber which can prevent colon cancer and improve digestion.

As a medicinal ingredient (anticoagulant, rich in fiber which can prevent colon cancer, improve digestion, increase water content in the feces). Antibiotics, antihehmethes, antihypertensive agents, cholesterol-reducing agents, dilatory agents, and insecticides Improve the body's defense function, improve the system work of the heart and blood circulation, as well as the 
digestive system Traditional medicine for coughs, asthma, bronchitis, tuberculosis, intestinal worms, stomach aches, fever, rheumatism, the protein content of seaweed is important for forming new tissue in the skin, thus preventing premature aging. can increase sexual power. The content of iodine is needed by the body to prevent goiter. It is also good for diet, reduces the risk of obesity, the fiber in seaweed is filling and the carbohydrate content is difficult to digest so it will cause a feeling of full longer.

One of the elements contained in seaweed is calcium, it is known that the calcium content in seaweed is up to 10 times higher than milk. Therefore, seaweed is often used as an antiosteoporosis drug. Plants whose habitat in the sea are also rich in minerals, amino acids, nucleic acids, carbohydrates, sugars, and various vitamins. Several types of minerals are contained in seaweed, including iron, iodine, aluminum, manganese, calcium, nitrogen, phosphorus., sulfur, silicon, chlorine, barium, titanium, and potassium. Of the many elements contained in Seaweed, the most elements are carbohydrates. Interestingly, carbohydrates in seaweed consist of gumi compounds, which are polysaccharide polymer compounds in the form of fibers. because it is not surprising that seaweed contains lots of fiber. This fiber is dietary fiber, which is fiber with only a small amount of carbohydrates that can be absorbed by the body. Indonesian people, both in urban and rural areas, are very fond of this food. Instant noodles, for example, are so popular with many people because they are relatively cheap and easy to cook, if the added content of seaweed exceeds 30 percent, the noodles will become mushy or no longer chewy.

\section{How to Get Rid of Fishy Odor in Seaweed}

How to get rid of the fishy smell of seaweed is by washing it clean first and then giving it lime juice, apart from giving lime juice it can also be done by soaking seaweed in lime water for 12 hours. After soaking, washed and given lime again. That way the fishy smell in seaweed can be lost

\section{Making Seaweed Noodles}

In making seaweed noodles, there are several steps, tools and materials, namely as follows: Tools and Materials (1) Knife, (2) Scales, (3) Basin, (4) Bucket, (5) Spoon, (6) Wood used for thinning (7) Markatto, (8) Strainers, (9) Stoves (10) Wooden rollers. Ingredients: (1) Seaweed (25\%) (2) Cassava Flour (3) Spices (4) Lime water (5) Lime, (6) Egg, (7) Water (250 ml)

Procedure: (1) Seaweed is cleaned first and soaked in lime water, (2) After that, weigh 25\% of the cassava flour and seaweed, (3) Blend the seaweed first, (4) All dry ingredients (cassava flour) and seaweed are mixed evenly in the container, (5) Spices dissolved in water, (6) In the flour mixture in a container, make a curve in the middle of which is filled with eggs, ingredients and spices in a water solution, then stir everything slowly using your hand or a spoon, (7) All mixture ingredients must be well mixed and formed a dough, (8) Then the dough is perfected or dikalis, kneading can be done on the table using wood, (9) Cover the dough with plastic, then let stand for 30 minutes and then knead again, (10) The dough is cut and divided into several equal sizes, then flatten using wood, (11) The dough sheet is thinned using markatto with a thickness of 1-4 cm, (12) Cut the dough sheet using the markatto so that the noodle ropes are formed. At this stage, raw noodles are still formed. Then process the noodles into various kinds of noodles.

In making seaweed noodles, only $25 \%$ of seaweed is needed, because if more seaweed is used in making these noodles, the resulting noodles will become mushy. In the manufacture of 
seaweed noodles, the seaweed used is medium sized seaweed, not too old and young and brown.

\section{Increase Incomes for Coastal Communities}

There are quite a lot of Seaweed in Probolinggo Regency, especially in Curahsawo Village, but the coastal communities do not know how to use the Seaweed. This is due to a lack of knowledge or human resources for coastal communities. The income of the people of Curahsawo Village is minimal, therefore the researchers made seaweed noodles in order to increase the income of the coastal communities to be better than before. And seaweed can be used properly too.

\section{Conclusion}

Based on the literature review, Seaweed (Eucheuma cottonii) and cassava flour have a lot of protein content so that they can be made into something of high value, namely seaweed noodles, because the ingredients are easy to obtain and good for consumption by the body's growth. Apart from being easy to get, seaweed (Eucheuma cottonii) and cassava are also environmentally friendly because they come from natural ingredients and do not endanger health. In the manufacture of seaweed noodles, which are used in making seaweed noodles are fresh cassava flour and seaweed (Eucheuma cottonii). Seaweed that is clean and not fishy and has also been blended, mixed with cassava which has become flour. From the mixing and several steps used to make Seaweed noodles. From the above steps, a new product that is more useful and harmless to the body is obtained, namely seaweed noodles. The many benefits for our health, so that people do not have to worry about these seaweed noodles. In coastal areas there is a lot of seaweed, but the people do not use it.

\section{References}

Dhargalkar, V. K., \& Pereira, N. (2005). Seaweed: promising plant of the millennium.

Dawes, C. J., \& Mathieson, A. C. (2008). The seaweeds of Florida. University Press of Florida.

Deshmukhe, G. V., Dhargalkar, V. K., \& Untawale, A. G. (2001). Seaweed resources. Oxford and IBH, New Delhi.

Doty, M. S., Caddy, J. F., Santelices, B., \& Santelices, B. (Eds.). (1987). Case studies of seven commercial seaweed resources (No. 281-282). Food \& Agriculture Org.

Ferdouse, F., Holdt, S. L., Smith, R., Murúa, P., \& Yang, Z. (2018). The global status of seaweed production, trade and utilization. Globefish Research Programme, 124, I.

Hwang, E. K., \& Park, C. S. (2020). Seaweed cultivation and utilization of Korea. Algae, 35(2), 107-121.

Rebours, C., Marinho-Soriano, E., Zertuche-González, J. A., Hayashi, L., Vásquez, J. A., Kradolfer, P., ... \& Hovelsrud, G. (2014). Seaweeds: an opportunity for wealth and sustainable livelihood for coastal communities. Journal of Applied Phycology, 26(5), 1939-1951.

Reilly, P., O'doherty, J. V., Pierce, K. M., Callan, J. J., O'sullivan, J. T., \& Sweeney, T. (2008). The effects of seaweed extract inclusion on gut morphology, selected intestinal microbiota, nutrient digestibility, volatile fatty acid concentrations and the immune status of the weaned pig. Animal: an international journal of animal bioscience, 2(10), 1465. 
Seghetta, M., Tørring, D., Bruhn, A., \& Thomsen, M. (2016). Bioextraction potential of seaweed in Denmark-An instrument for circular nutrient management. Science of the Total Environment, 563, 513-529.

Ugarte, R. A., Sharp, G., \& Moore, B. (2006). Changes in the brown seaweed Ascophyllum nodosum (L.) Le Jol. Plant morphology and biomass produced by cutter rake harvests in southern New Brunswick, Canada. In Eighteenth International Seaweed Symposium (pp. 125-133). Springer, Dordrecht. 